doi: 10.52370/TISC21316MM

\title{
THE STATE AND PERSPECTIVE OF TOURISM IN SERBIA: THE IMPACT OF THE COVID-19 ON THE TOURISM MARKET
}

\author{
Marija Mandarićl ${ }^{1}$ Dejan Sekulić ${ }^{2}$
}

\begin{abstract}
The COVID-19 of significantly affects the global economic, health, political, socio-cultural systems. The impacts of COVID-19 show a tendency that this crisis may have long-term structural changes in tourism as a socio-economic activity and industry. The paper discusses the impact of COVID-19 on tourism in Serbia. The aim of the paper is to identify the fundamental values, institutions, chalenges and limitations that the tourism industry and academia should perceive, in order to advance the research and tourism practice frontiers. It is necessary to investigate the state and perspective of the tourist market in Serbia, in order to give recommendations and contribution to the recovery of tourism activity after COVID-19.
\end{abstract}

Key Words: Tourism, COVID-19, Tourism market, Crises, Serbia JEL classification: D11, M21, M31, Z30

\section{Introduction}

The World Health Organization declared a pandemic of the Covid-19 virus on March 12, 2020, and since then, many institutions have been forced to organize their business differently. In most branches, faster or slower, the business process was adjusted and operations continued. However, with the pandemic, the growth and development of the world tourism industry was completely stopped. According to Deb \& Nafi (2020) "the tourism and travel industry is one of the world's biggest industries, offering rich

\footnotetext{
${ }^{1}$ Marija Mandarić, PhD, Associate Professor, Faculty of Hotel Management and Tourism, University of Kragujevac, Vojvodjanska 5a, Vrnjačka Banja, +381642590099, mmandaric@kg.ac.rs

${ }^{2}$ Dejan Sekulić, PhD, Ássistent Professor, Faculty of Hotel Management and Tourism, University of Kragujevac, Vojvodjanska 5a, Vrnjačka Banja, +38162602902, dejan.sekulic@kg.ac.rs
} 
experiences to travelers and contributing to community development" (p. 1486). Closing borders, cities, ports, airports, hotels, restaurants, museums, isolation measures and social distancing have become insurmountable barriers to international tourism. The COVID-19 pandemic has affected people's lives and economic activity worldwide. It is clear that "the virus has been a major public health challenge in all countries and the governments have taken drastic measures to protect their citizens" (Mihai \& Toma, 2020, p. 433).

Strategies and measures of health communication in Serbia (e.g. social distancing, contact bans, locking down in certain countries, stay- at- home campaigns, self-isolation or mandatory quarantine, limiting the number of people in a certain area, etc.) have stopped, above all, international traveling and tourism, but not the desires of the local population to spend a shorter or longer vacation in domestic destinations. During the summer season of 2020, as well as during the winter season of 2020/2021, it was difficult to find a vacancy in spa and mountain centers throughout the Republic of Serbia. The question is whether the growth of interest in domestic destinations is sustainable in the long run even after the pandemic, if it is possible for domestic tourism to use the indicated trust of tourists during COVID-19 and link them to itself. Is the behavior of domestic tourists affected by COVID-19 and in what way? Can future creators of the tourism industry estimate the consequences of COVID? This paper compares the effects of COVID-19 on global tourism with effects on domestic tourism and explores how the pandemic could change tourist behavior and tourism.

\section{Pandemics, tourism and global change}

Globalization, as an economic process, began to take place on the foundation of the new information and telecommunication technology at the end of the 20th and the beginning of the 21st century and enabled connecting the world into a whole (Mandarić \& Sekulić, 2018). It has been noticed that "tourism has a significant impact on the economic, sociocultural, ecological and functional development of destinations" (Mandarić et al., 2017, p. 787). The pandemic spread rapidly and affected both developed and developing countries and underdeveloped countries, leaving consequences on the economies of all countries. The negative impact of the pandemic affected all sectors of the economy, and it turned out that tourism and hospitality were affected in particular. Tourism is the leading economic branch of the global economy that contributes to the 
growth of national economies, employment of the population and the creation of conditions for a better life, both in developed and developing countries. For decades, "the global travel and tourism industry has experienced continuous growth and has contributed to approximately $10 \%$ of the global GDP" (Deb \& Nafi, 2020, p. 1488) and 10\% of employees worldwide work in tourism. Tourism is sector of the economy that is sensitive to numerous environmental, political and socio-economic risks, but it has managed to withstand numerous and various crises (e.g. terrorism, earthquakes, Ebola, SARS, etc.). In addition to COVID-19, which is currently the biggest challenge for the tourism industry, significant challenges for tourism are the health situation (in general) and climate change (Deb \& Nafi, 2020). The impact of COVID-19 so far shows signs that this crisis is not only different from others, but that it will have farreaching and numerous effects for tourism (Sigala, 2020). It can be assumed that "the actual impacts of the COVID-19 outbreak on tourism will not be apparent until after the pandemic has ended" (Deb \& Nafi, 2020, p. 1488).

The negative impact of the pandemic on global tourism continues in 2021, compared to January 2020, the data show a decline in international tourist arrivals of $87 \%$ in January 2021 (UNWTO, 2021a). The first predictions made by the UNWTO were that international arrivals would fall between $20 \%$ and 30\% compared to 2019 (Gossling et al., 2020). Nevertheless, data from The World Tourism Organization (UNWTO, 2021b) indicate that international tourist arrivals declined by $74 \%$ in 2020 compared to the previous year and "that equates to a decline of around 1 billion international arrivals, bringing the industry back to levels last seen in the late 1980s". The interruption of international travel represents an estimated loss of USD 1.3 trillion in export revenues. Also, pandemic has put between 100 and 120 million direct tourism jobs at risk, many of them in small and mediumsized enterprises.

In Figure 1. we can see that "Asia and the Pacific (-96\%), the region which continues to have the highest level of travel restrictions in place, recorded the largest decrease in international arrivals in January. Europe and Africa both saw a decline of $85 \%$ in arrivals, while the Middle East recorded a drop of $84 \%$. International arrivals in the Americas decreased by $77 \%$ in January, following somewhat better results in the last quarter of the year" (UNWTO, 2021a). 
Figure 1: Change in international tourist arrivals 2019-2021 January

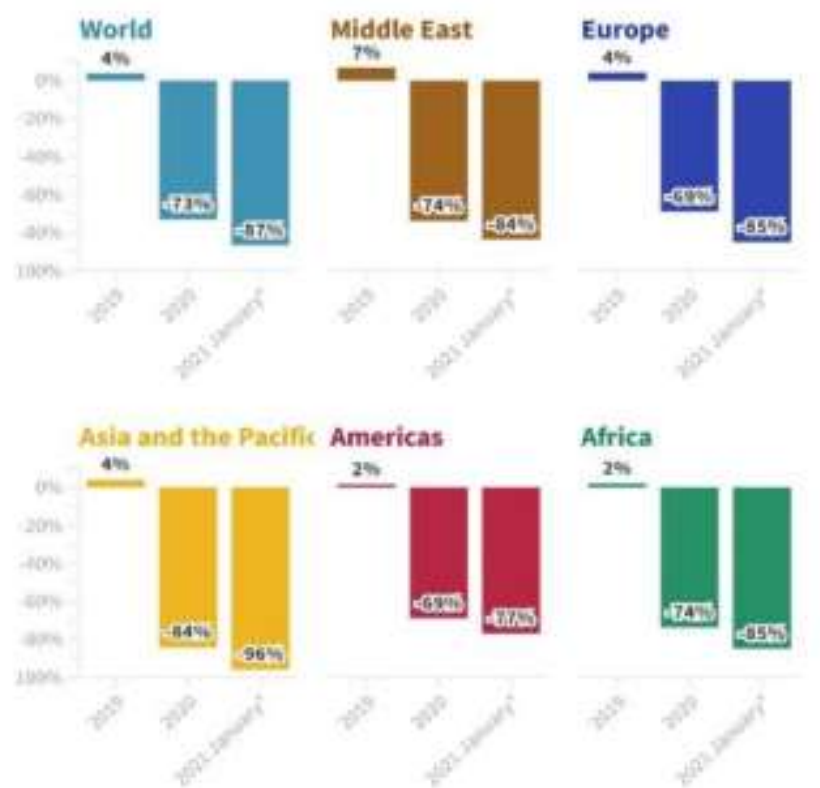

Source: World Tourism Organization - UNWTO, (2021a), Tourist Arrivals Down 87\% In January 2021 As Unwto Calls For Stronger Coordination To Restart Tourism, https://www.unwto.org/news/tourist-arrivals-down87-in-january-2021-as-unwto-calls-for-stronger-coordination-to-restarttourism, (04 April 2021)

It is estimated that during the pandemic, about $90 \%$ of the world's population was forced to stay at home, which completely changed the tourism and hospitality industry. "Based on current trends, UNWTO expects international tourist arrivals to be down about $85 \%$ in the first quarter of 2021 over the same period of 2019. This would represent a loss of some 260 million international arrivals when compared to pre-pandemic levels" (UNWTO, 2021a).

\section{Pandemics and tourism in Serbia}

It is quite certain that the pandemic caused economic and social consequences for all countries in the world, but the greater impact of the pandemic was present in countries whose GDP is more dependent on tourism, especially in "small and less developed countries where tourism accounts for over $50 \%$ of gross domestic product" (Luković \& Stojković, 2020, p. 83). In Serbia, the Republic Bureau of Statistics monitors only the 
direct contribution of tourism to the gross domestic product (accommodation and food services), which is just a partial monitoring of this activity.

The impact of the pandemic on tourism in Serbia can be observed in two ways, through the reduction or complete cessation of business activities of certain economic entities in tourism (travel agencies, city hotels, etc.), but also through the prism of great interest of domestic tourists to stay and rest in domestic tourist destinations, which has caused for some tourist entities to suffer the crisis in business much less. Observing the official data on tourist turnover in Serbia in the first two months of 2021 compared to January and February 2019, it can be observed that domestic tourism, thanks to spa and mountain destinations, achieved a significantly smaller decrease in the number of guests compared to global tourism.

Namely, according to the Republic Bureau of Statistics (2021) in the Republic of Serbia in January 2021, compared to January 2020, the number of tourist arrivals decreased by $40.4 \%$, and the number of overnight stays decreased by $34.8 \%$. In January 2021, compared to January 2020, the number of overnights of domestic tourists decreased by $10.7 \%$, and the number of overnights of foreign tourists decreased by $66.9 \%$. In February 2021, compared to February 2020, the number of tourist arrivals decreased by $38.0 \%$, and the number of overnights decreased by $34.9 \%$. In February 2021, compared to February 2020, the number of overnights of domestic tourists decreased by $24.7 \%$, and the number of overnights of foreign tourists decreased by $56.4 \%$.

According to the data of the Ministry of Trade, Tourism and Telecommunications (2021), in the first two months of 2021, the total number of tourist arrivals in the Republic of Serbia was 276,094 (a decrease of $39.1 \%$ compared to the same period in 2020), out of which the domestic tourist arrivals accounted for 217,607 (a decrease of $14.8 \%$ ), i.e. they participated with $78.8 \%$ in total arrivals. The number of foreign tourist arrivals was 58,487 (a decrease of $70.5 \%$ compared to the same period in 2020), which represents a share of $21.2 \%$ in total tourist arrivals.

The following is also interesting, in the first two months of 2021, Belgrade had a total of 40,447 arrivals, i.e. a decrease of $68.5 \%$, while the number of arrivals of domestic tourists $(15,027)$ decreased by $37.8 \%$ compared to the same period in 2020 , and the number of arrivals of foreigners $(25,420)$ by $75.6 \%$. In Novi Sad, the tourist turnover expressed by the number of 
arrivals amounted to 10,660 , which is a decrease of $48.1 \%$, where domestic tourists $(6,980)$ decreased by $16.2 \%$, and foreign $(3,680)$ by $69.9 \%$. However, in spas, there was a significantly smaller decline in the total number of arrivals $(48,298)$ of $26.6 \%$, of which domestic tourists $(44,222)$ had a decline of $17.7 \%$, and foreign $(4,076)$ a decline of $66.1 \%$. A total of 122,179 arrivals were registered in mountain centers, which is a decrease of $15.6 \%$ compared to the same period in 2020 . The number of domestic tourists $(108,946)$ decreased by $3.9 \%$, while the number of foreign tourists $(13,233)$ decreased by $57,8 \%$.

In such circumstances, when domestic tourists continue to travel during a pandemic, the question arises as to whether something changes in their expectations of travel, current behavior, and future behavior. Also, the question arises, whether the interest of tourists to visit domestic destinations is sustainable even after the pandemic.

\section{The impact of COVID-19 on Tourist consumption behaviour}

During and after the pandemic, it is necessary for tourism workers to manage the crisis in order for the industry to recover faster. One of the challenges they face is researching and understanding the behavior of tourists. Tourist behavior is the combination of interactions between internal factors, which depend on the personality of the tourist and external factors that depend on the environment. Collection and analysis of data on changes in tourist behavior will be crucial for success in tourism. Understanding fears, future expectations and knowing the factors that tourists consider as important when choosing a destination can help overcome the crisis. As a result of the crisis caused by the pandemic, people have begun to reconsider their way of life, pay more attention to health information and focus on how to improve physical and mental health. The relationship between the pandemic and travel is becoming the key to understanding the importance of health security and change in tourism (Gössling et al., 2021).

According to Jiang \& Wen (2020) "due to the global health crisis caused by COVID-19, travelers are now likely to pay more attention to the availability and quality of medical facilities when making travel decisions" (p. 9). The results of the conducted studies indicate that, only "destinations can attract visitors if they provide a safe and secure environment in which travellers feel protected from threats during their stay" (Chebli \& Ben, 2020, p. 197). Hygiene and cleanliness are common topics when analyzing 
consumer behavior in tourism and hospitality literature (Kaushal \& Srivastava, 2021). Hygiene and cleanliness will be increasingly important factors for successful business in the service sector, especially in tourism. When considering the recovery of tourism after COVID-19, the focus should be on hygiene and cleanliness as well as the safety aspect. The health aspects of the tourist offer will be crucial for the recovery of tourism after COVID-19 (Wen \& Jiang, 2020).

People are expected to be afraid to travel far from home, and to prefer domestic destinations, relatively close to home. The personal car will be used for travel, rather than tourist transportation services. Also, sustainable tourism (ecotourism, rural tourism, medical, spa, mountain) will be in better position, because people after the pandemic will need to spend more time in nature, preferring outdoor activities where measures of social distance can be provided and where they feel safer (Mihai \& Toma, 2020). Based on all the above, the goal of the research is defined.

\section{Research methodology}

The survey was conducted with the aim of investigating the attitudes of students at the Faculty of Hotel Management and Tourism in Vrnjačka Banja regarding the impact of the COVID pandemic on the behavior of tourists and domestic tourism. The students of the Faculty were chosen because they are the future creators of the tourist offer and demand in the Republic of Serbia. The study should also point out the factors that will influence the further development of tourism in Serbia. An insight into the literature has been observed that "tourism and hospitality related studies in light of COVID-19 crisis are only starting to emerge at this point" (Kaushal \& Srivastava, 2021, p. 3). Studies have been published analyzing the impact of COVID on tourism, however there are no papers that have explored the perceptions of tourism and hospitality students about changes in tourism due to COVID.

The research is based on the review of relevant domestic and foreign literature and a similar research. A foreign study investigates changes in tourist behavior and the effects of COVID-19 on tourism, which relate to: the choice of destination near the region in which they live; the choice of a lesser-known destination, where there will be fewer tourists; avoiding group travels, checking the cleanliness conditions of the destination; informing about the quality of health care of the destination; careful examination of travel insurance choices (Chebli \& Ben, 2020). 
The questions in the questionnaire for our empirical research are tailored to the research objectives of students' attitudes about tourist behavior during and after COVID-19 and changes in tourism. The questionnaire is designed so that in addition to the part related to the questions about the respondent, it includes two more parts. The first three introductory questions within the first part of the questionnaire refer to the basic data of the respondents. The second part of the questionnaire covered statements related to the period during COVID-19 and the period after the pandemic, when tourists prepare for travel. The goal was to investigate the extent to which the health crisis caused by the COVID-19 pandemic will change the perception of travel and affect tourism in Serbia. The statements refer to changes in the behavior of tourists and the respondents were asked to express the degree of agreement with them. A five-point Likert scale was used, ranging from (1) I completely disagree, (2) I disagree, (3) I have no opinion (neither agree nor disagree), (4) I agree, to (5) I totally agree. The third part of the questionnaire included a question with multiple answers related to the factors influencing changes in domestic tourism. The validity of the survey content was applied when changes were made to the survey structure.

The survey was generated using Google questionnaires and distributed via email. The survey was sent to all undergraduate, master's and PhD students at the Faculty of Hospitality and Tourism in Vrnjačka Banja, University of Kragujevac in March 2021. The reason why it was distributed to students of all levels of study is the following: in addition to wanting to have as many respondents as possible, we thought that students at different levels of study would have different perceptions of changes in tourist behavior due to the pandemic. A total of 202 students participated in the research and after checking the answers, it was determined that all completed questionnaires were valid.

\section{Data analysis and discussion of results}

The sample was observed according to the following characteristics: gender, age and level of study. When it comes to the observed characteristics of the sample, the majority of the sample are female respondents $149(73.8 \%)$ compared to 53 of male (26.2\%) who participated in the study. Students of the Faculty of Hotel Management and Tourism ranged in age were from 18 to 61, while the average age of students was 24.33 years. By observing the respondents according to the level of study, it was determined that most of them are undergraduate students, 143 
(70.8\%), followed by master students, $33(16.3 \%)$ and the fewest were $\mathrm{PhD}$ students $26(12.9 \%)$.

Data processing is performed with the support of the Statistical Package for Social Sciences IBM SPSS Statistics, Version 23. The significance level $\alpha$ $=0.05$ and the $p$ value less than 0.05 were used to determine the statistical significance. All tests were performed with a $95 \%$ confidence interval. For descriptive presentation of data, for categorical variables (gender of respondents, level of studies, etc.), values of absolute and relative frequency were used, while data were graphically presented using a pie diagram. For variables whose answers were defined by the Likert scale, tables and histograms were used. The mean value and standard deviation, as well as the median, were used to describe the variables whose answers were defined by the Likert scale, while the data were graphically represented using histograms.

The reliability of the observed statements is measured and based on the value of the Cronbach's alpha coefficient. The value of the Cronbach's alpha coefficient, observed for the group of questions related to the period during the COVID-19 pandemic is 0.721 and for the group of questions related to the period after the COVID-19 pandemic is 0.802 . The obtained values indicate high reliability and consistency of the statements, since the values are higher than the recommended minimum value of 0.7 (Nunnally, 1978).

The paper analyzes the characteristics of the sample using descriptive statistics and significance tests. The Man-Whitney test, the one-factor ANOVA, and the Wilcoxon test were used to analyze the difference in statements. Testing the direction and strength of the relationship between statements is performed by applying correlation analysis.

Table 1: Behavior of tourists during and after a pandemic

\begin{tabular}{|c|c|c|c|c|c|c|}
\hline \multirow{2}{*}{ Statements } & \multicolumn{2}{|c|}{ During the pandemic } & \multicolumn{2}{|c|}{ After the pandemic } \\
\cline { 2 - 7 } & Mean & $\begin{array}{c}\text { Std. } \\
\text { dev. }\end{array}$ & Median & Mean & $\begin{array}{c}\text { Std. } \\
\text { dev. }\end{array}$ & Median \\
\hline $\begin{array}{c}\text { Q1. They choose a } \\
\text { destination near the region } \\
\text { in which they live. }\end{array}$ & 3,78 & 1,13 & 4 & 2,59 & 1,35 & 2 \\
\hline $\begin{array}{c}\text { Q2. They choose a } \\
\text { destination they haven't } \\
\text { been to before. }\end{array}$ & 3,50 & 1,14 & 4 & 4,05 & 1,13 & 4 \\
\hline
\end{tabular}




\begin{tabular}{|c|c|c|c|c|c|c|}
\hline $\begin{array}{c}\text { Q3. Choose lesser-known } \\
\text { destination, where less } \\
\text { tourist crowds. }\end{array}$ & 3,65 & 1,22 & 4 & 3,05 & 1,27 & 3 \\
\hline $\begin{array}{c}\text { Q4. They avoid group } \\
\text { travel by bus, boat, } \\
\text { plane... }\end{array}$ & 3,50 & 1,30 & 4 & 2,72 & 1,35 & 3 \\
\hline $\begin{array}{c}\text { Q5. They follow health } \\
\text { information related to a } \\
\text { destination where travel. }\end{array}$ & 3,87 & 1,08 & 4 & 3,55 & 1,24 & 4 \\
\hline $\begin{array}{c}\text { Q6. They choose } \\
\text { accommodation facilities } \\
\text { that take special care of } \\
\text { health and hygiene and } \\
\text { check sanitary conditions } \\
\text { (hygiene, cleanliness). }\end{array}$ & 4,00 & 1,08 & 4 & 3,88 & 1,15 & 4 \\
\hline $\begin{array}{c}\text { Q7. They choose carefully } \\
\text { travel insurance. }\end{array}$ & 3,93 & 1,09 & 4 & 3,88 & 1,11 & 4 \\
\hline
\end{tabular}

Source: Authors

Observing the results of descriptive statistics (Table 1.) during the pandemic, we can notice that the greatest value of the arithmetic mean has the statement "They choose accommodation facilities that take special care of health and hygiene and check sanitary conditions (hygiene, cleanliness)" $($ Mean $=4)$. After the pandemic, the statement "They choose a destination they haven't been to before" has the highest value of the arithmetic mean $($ Mean $=4.05)$. The lowest rated statements (during COVID) are "They choose a destination they haven't been to before" (Mean = 3.5) and "They avoid group travel by bus, boat, plane... etc." (Mean = 3.5). The lowest rated statement (after COVID) is "They choose a destination near the region in which they live" (Mean $=2.59$ ). It is interesting that, while the best rated statement after the pandemic is "They choose a destination they have not been to before", at the same time it is the lowest rated statement during the pandemic. The results support the conclusion that the respondents believe that tourists during the pandemic are ready to stay in places where they have already been before, but that after the pandemic they will want to visit some new places where they have not yet been. This behavior is expected because the current restriction of movement and the special effort that the tourist should invest in checking health, but also other travel information regarding the new destination significantly affects the choice of destination. 
The Mann-Whitney test was used to analyze the difference in attitudes during and after the pandemic between women and men.

Graph 1: Difference in statements before the pandemic

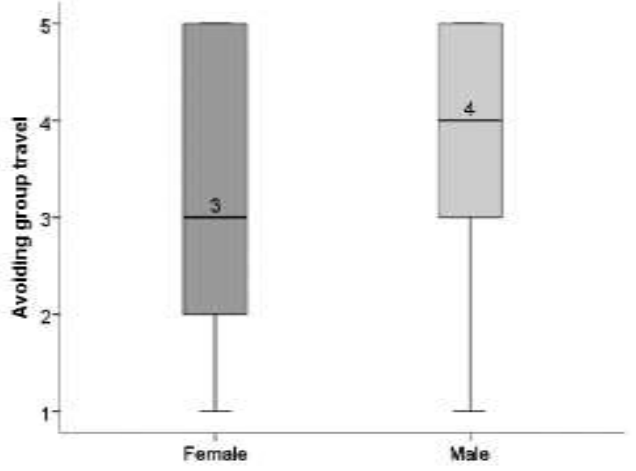

Source: Authors

The results show (Graph 1) that during the pandemic, there is a statistically significant difference $(\mathrm{p}=0.025)$ in the attitudes between men and women about avoiding group travel, with men $(M=4)$ more than women $(M=3)$ believing that they should be cautious.

The results of the Mann-Whitney test show that, after the pandemic, there is a statistically significant difference in attitudes on the two issues.

Graph 2: Difference in attitudes after a pandemic
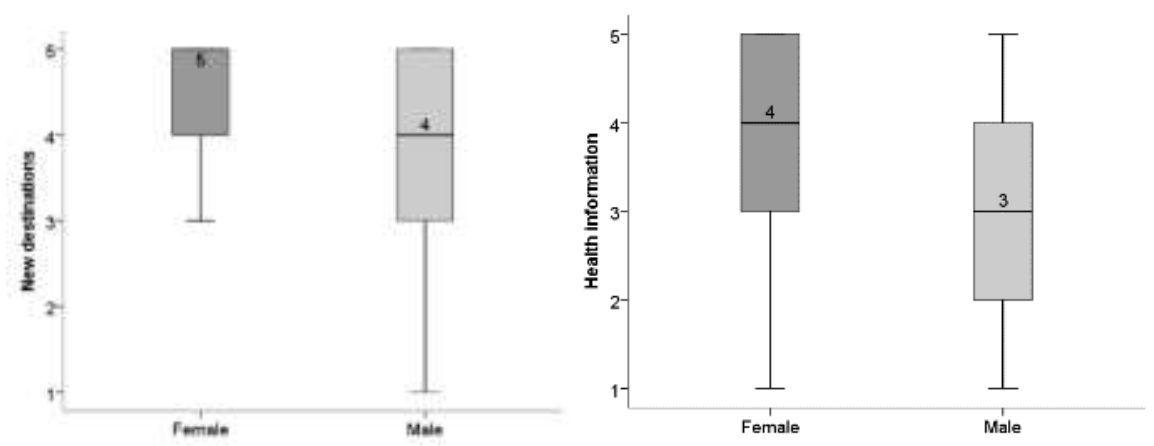

Source: Authors

According to Graph 2, when choosing destinations where they did not stay before (new destinations) $(\mathrm{p}=0.025)$, it is more important for women (M 
=5) than men $(M=4)$. Also, it can be noticed regarding the monitoring of health information related to the destination where they travel and informing about the quality of the health care system at the destination ( $\mathrm{p}$ $=0.007)$, women $(M=4)$ take greater care of this point than men $(M=3)$.

To analyze the relationship between attitudes during and after the pandemic with the age of the respondents, we used the correlation method, i.e. we interpreted Spearman's correlation coefficient (Table 2). There is a statistically significant $(\mathrm{p}=0.000)$, positive and medium correlation between the attitude of students that tourists choose a destination near the region in which they live and their age $(\rho=0.275)$, i.e. with age, this attitude increases. There is a statistically significant $(\mathrm{p}=0.019)$, positive and weak correlation between the attitude of students that tourists avoid group travel (by bus, plane... etc.) and their age $(\rho=0.165)$, i.e. as they get older, this attitude intensifies.

Table 2: Relationship between respondents' attitudes and age

\begin{tabular}{|c|c|c|c|c|c|c|}
\hline \multirow{2}{*}{ Questions } & \multicolumn{3}{|c|}{ During COVID-19 } & \multicolumn{3}{c|}{ After COVID-19 } \\
\cline { 2 - 7 } & Ro & $\mathbf{N}$ & $\mathbf{p}$ & $\mathbf{R o}$ & $\mathbf{N}$ & $\mathbf{p}$ \\
\hline Q1 & $0,275^{* *}$ & 202 & 0,000 & 0,084 & 202 & 0,234 \\
\hline Q2 & $-0,003$ & 202 & 0,968 & $-0,084$ & 202 & 0,232 \\
\hline Q3 & 0,119 & 202 & 0,091 & 0,115 & 202 & 0,103 \\
\hline Q4 & $0,165^{*}$ & 202 & 0,019 & 0,064 & 202 & 0,369 \\
\hline Q5 & $0,151^{*}$ & 202 & 0,032 & 0,054 & 202 & 0,448 \\
\hline Q6 & 0,005 & 202 & 0,941 & $-0,096$ & 202 & 0,172 \\
\hline Q7 & $-0,026$ & 202 & 0,713 & $-0,052$ & 202 & 0,466 \\
\hline
\end{tabular}

Source: Authors

Also, there is (Table 2) a statistically significant ( $\mathrm{p}=0.032)$, positive and weak correlation between the attitude of students that tourists follow health information related to the destination where they travel and their age $(\rho=$ 0.151 ), i.e. as they grow older this attitude intensifies. After a pandemic, there are no statistically significant correlations.

To analyze the difference in the attitudes of respondents during the pandemic in relation to the level of studies among students and education among citizens, we used a one-factor ANOVA for different groups with subsequent. 
There is (Table 3 ) a statistically significant difference in attitudes for three questions between undergraduate and master's students (during a pandemic), as follows:

- When choosing a destination near the region in which they live ( $\mathrm{p}=$ $0.000)$, significantly more attention to that matter is paid by master's students $(\mathrm{M}=4.36)$ compared to undergraduate students $(\mathrm{M}=3.59)$;

- When avoiding group travels $(\mathrm{p}=0.018)$, significantly more attention is paid to that matter by master's students $(\mathrm{M}=4.00)$ compared to undergraduate students $(\mathrm{M}=3.34)$;

- When monitoring the quality of health care at the destination $(\mathrm{p}=$ 0.013), significantly more attention is paid to this matter by master's students $(\mathrm{M}=4.30)$ compared to undergraduate students $(\mathrm{M}=3.73)$.

Table 3: Difference in respondents' attitudes

\begin{tabular}{|c|c|c|c|c|c|c|}
\hline \multirow{2}{*}{ Questions } & \multicolumn{3}{|c|}{ During COVID-19 } & \multicolumn{3}{c|}{ After COVID-19 } \\
\cline { 2 - 7 } & F & p & Note & F & p & Note \\
\hline Q1 & 8,107 & 0,000 & $1-20,001$ & 1,879 & 0,156 & \\
\hline Q2 & 1,246 & 0,290 & & 0,795 & 0,453 & \\
\hline Q3 & 2,647 & 0,074 & & 3,971 & 0,020 & $1-20,022$ \\
\hline Q4 & 4,080 & 0,018 & $1-20,022$ & 0,737 & 0,480 & \\
\hline Q5 & 4,439 & 0,013 & $1-20,016$ & 0,716 & 0,490 & \\
\hline Q6 & 0,952 & 0,388 & & 1,148 & 0,319 & \\
\hline Q7 & 2,631 & 0,074 & & 1,421 & 0,244 & \\
\hline
\end{tabular}

*1 - undergraduate; 2 - master studies

Source: Authors

After the pandemic, there is a statistically significant difference in attitudes when choosing lesser-known destinations where there are fewer tourists and it is less crowded $(\mathrm{p}=0.022)$, with significantly more attention paid to that matter by master's students $(\mathrm{M}=3.61)$ compared to undergraduate students $(M=2.96)$. It can be noticed that master's students are more careful in understanding the current and future behavior of tourists, which is somewhat expected. Education in a certain area implies greater responsibility of the professionals.

The Wilcox test was used to analyze the difference in attitudes during and after the pandemic, since we compared the responses of the same respondents.

The analysis (Table 4) showed that students believe that tourists will pay less attention to the factors listed in the research after the pandemic. It was 
determined that there is a statistically significant difference in responses during / after the pandemic in five questions, as follows:

- When choosing a destination near the region in which they live $(\mathrm{p}=$ 0.000 ), where they consider that this factor is more important during ( $\mathrm{M}$ =4) than after the pandemic $(\mathrm{M}=2)$;

- when choosing a destination where they have not stayed before $(\mathrm{p}=$ $0.000)$, where they consider that this factor is equal during $(\mathrm{M}=4)$, and after the pandemic $(\mathrm{M}=4)$;

- when choosing lesser-known destinations $(p=0.000)$, where they consider that this factor is more important during $(M=4)$ than after the pandemic $(\mathrm{M}=3)$;

- when avoiding group travel by bus, plane... $(\mathrm{p}=0.000)$, where they consider that this factor is more important during $(\mathrm{M}=4)$ than after the pandemic $(\mathrm{M}=3)$;

- when monitoring health information related to the destination where they travel $(\mathrm{p}=0.001)$, where they consider that this factor is equally important during $(M=4)$, and after the pandemic $(M=4)$.

Table 4: Comparison of respondents' attitudes

\begin{tabular}{|c|c|c|c|}
\hline \multirow{2}{*}{ Questions } & \multirow{2}{*}{$\mathbf{p}$} & \multicolumn{2}{|c|}{ Median } \\
\cline { 3 - 4 } & & During COVID-19 & After COVID-19 \\
\hline Q1 & 0,000 & 4 & 2 \\
\hline Q2 & 0,000 & 4 & 4 \\
\hline Q3 & 0,000 & 4 & 3 \\
\hline Q4 & 0,000 & 4 & 3 \\
\hline Q5 & 0,001 & 4 & 4 \\
\hline Q6 & 0,073 & 4 & 4 \\
\hline Q7 & 0,477 & 4 & 4 \\
\hline
\end{tabular}

Source: Authors

In order to better understand the way to how to keep domestic tourists in domestic destinations even after a pandemic, a multi-answer question was offered that reveals the reasons why students believe that tourists will be interested in domestic tourism. The largest number of students, 92 of them $(45.3 \%)$ believe that the greater interest of tourists in domestic tourism, after the pandemic, will be most caused by a richer and more diverse offer of tourist destinations, 56 students $(27.7 \%)$ believe that lower prices of tourist services can motivate tourists to remain loyal, 29 students $(14.4 \%)$ believe that the state incentive through vouchers with a larger amount of money per voucher can support the further development of domestic 
tourism and only 25 students $(12.4 \%)$ believe that increasing the quality of services is crucial for the development of domestic tourism.

After the end of the Covid-19 pandemic, the tourist industry in Serbia will certainly experience changes as a result of modified attitudes and behavior of tourists. What will certainly be taken into account when tourists are in question is a long-term respect for health and safety measures. Considering the potentials of Serbia for the development of rural tourism and the tendencies of development of all forms of sustainable tourism, even after COVID, domestic tourism has a good perspective, but it is necessary to prepare and provide tourist capacities to meet the highest health and hygiene standards.

\section{Conclusion}

This paper presents the review of the current situation in global and domestic tourism and the main possible consequences of the COVID-19 pandemic on tourist behavior now and in the coming period, using the forecasts of the students of the Faculty of Hotel Management and Tourism. The paper analyzes the possible effects of COVID-19 on domestic tourism and provides an overview of research results from the aspect of future destination selection, ways of traveling, the importance of hygienic accommodation conditions and health, safety and cleanliness at the destination.

It is difficult to estimate what the further development of tourism will be both on a global and national level, if the virus will be completely destroyed and how the states will regulate travel conditions. The world has experienced many epidemics and pandemics throughout history, but none has had as such serious consequences for the global economy as Covid-19. The global tourism industry has faced a huge crisis due to the global COVID-19 outbreak. What is noticeable, based on the insight into statistical data, is that global tourism is in a far bigger crisis than domestic tourism. The closure of borders, the abolition of international routes and the "stay at home" recommendations and measures had a negative impact on international tourism and affected the great interest of tourists to stay in domestic destinations, especially spas and mountain resorts in Serbia, during the pandemic.

The qualitative analysis carried out in the paper has a significant scientific contribution. The theoretical and practical contribution of the paper is 
reflected in a better understanding of the current situation in tourism, which is an important precondition for undertaking future measures. The paper starts from the assumption that due to the Covid-19 pandemic, tourism is undergoing certain transformations and thus the behavior of tourists is changing and new tourism strategies are needed. The results of the research showed that people will most likely avoid distant and new destinations during a pandemic and, conversely, after a pandemic, they will want to travel to new destinations, and their proximity will not be crucial. The reason for choosing less distant destinations during a pandemic is probably to reduce the risk of infection, but also the safety of travel in the country (crossing one or more borders increases the risk of some of them being closed). Such attitudes significantly affect domestic tourism. Avoidance of group travel, hygiene and health conditions of tourist destinations and accommodation facilities are becoming important factors influencing tourist decision-making.

Although the impact of the Covid-19 pandemic on the global economy and tourism is attracting the attention of many researchers, this research topic is still inadequately explored in the relevant literature. Certain limitations are noticed in the conducted research. The basic limitation is a sample made up of students, which is why the results of the research are limited to this population. In this regard, this paper can be the basis and a guideline for some future research. For example, it would be useful to conduct a comparative analysis of the attitudes of the students and the citizens (tourists), with a special emphasis on their behavior on tourism. Certainly, the crisis caused by COVID-19 should be seen as an opportunity for a detailed analysis in the tourism of each country, especially with an emphasis on the future development of domestic tourism.

\section{References}

1. Chebli, A., Ben, S. F. (2020). The Impact of Covid-19 on Tourist Consumption Behaviour: A Perspective Article. Journal of Tourism Management Research, Vol. 7, No. 2, 196-207.

2. Deb, S.K., Nafi, S.M. (2020). Impact of Covid-19 Pandemic on Tourism: Recovery Proposal for Future Tourism. GeoJournal of Tourism and Geosites, Vol. 33, No. 4, 1486-1492. 
3. Gössling, S., Scott, D., Hall, C. M. (2021). Pandemics, tourism and global change: a rapid assessment of COVID-19. Journal of Sustainable Tourism, Vol. 29, No. 1, 1-20.

4. Kaushal, V., Srivastava, S. (2021). Hospitality and tourism industry amid COVID-19 pandemic: Perspectives on challenges and learnings from India. International Journal of Hospitality Management, Vol. 92, 102707.

5. Luković, S., Stojković, D. (2020). Covid-19 pandemic and global tourism. Hotel and Tourism Management, Vol. 8, No. 2, 79-88.

6. Mandarić, M., Sekulić, D. (2018). Brand Management in the Function of Global Progress of Companies: Investigation of the Innovation and Information Technology Role. TISC - Tourism International Scientific Conference, Vrnjačka Banja, 3(1), 61-78.

7. Mandarić, M., Milićević, S., Sekulić, D. (2017). Traditional values in the function of promotion of Sumadija and Pomoravlje as rural tourism destinations. Economics of Agriculture, Vol. 64, No. 2, 787-802.

8. Mihai, D., Toma, S. (2020). The International Tourism and the COVID19 Pandemic - Present and Perspectives, "Ovidius" University Annals, Economic Sciences Series, Vol. 20, No. 1, 433-438.

9. Ministry of Trade, Tourism and Telecommunications, (2021), Statistički podaci o turističkom prometu u Republici Srbiji [Statistical data on tourist traffic in the Republic of Serbia], https://mtt.gov.rs/sektori/sektor-zaturizam/korisne-informacije-turisticki-promet-srbija-kategorizacija/, (03 April 2021).

10. Nunnally, J.C. (1978). Introduction to Psychological Measurement, McGraw-Hill, New York.

11. Republic Bureau of Statistics, (2021), https://www.stat.gov.rs/, (03 April 2021).

12. Sigala, M., (2020). Tourism and COVID-19: Impacts and implications for advancing and resetting industry and research. Journal of Business Research, Vol. 117, No. 2, 312-321. 
13. World Tourism Organization - UNWTO, (2021a), Tourist Arrivals Down 87\% In January 2021 As Unwto Calls For Stronger Coordination To Restart Tourism, https://www.unwto.org/news/tourist-arrivals-down87-in-january-2021-as-unwto-calls-for-stronger-coordination-to-restarttourism, (04 April 2021).

14. World Tourism Organization - UNWTO, (2021b), 2020: Worst Year In Tourism History With 1 Billion Fewer International Arrivals, https://www.unwto.org/news/2020-worst-year-in-tourism-history-with-1billion-fewer-international-arrivals, (04 April 2021).

15. Wen, J., Jiang, Y. (2020). Effects of COVID-19 on hotel marketing and management: a perspective article. International Journal of Contemporary Hospitality Management, Vol. 32 No. 8, 563-2573. 